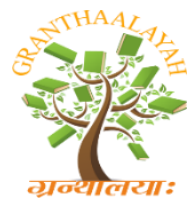

\author{
INTERNATIONAL JOURNAL OF RE
GRANTHAALAYAH \\ A knowledge Repository
}

Social

\title{
PARENTS OCCUPATION AND STUDENTS SELF-ESTEEM
}

\author{
Jerald C. Moneva ${ }^{\mathbf{1}}$, Genelyn G. Rozada ${ }^{2}$, Adrian M. Sollano ${ }^{3}$ \\ ${ }^{* 1,3}$ Mandaue City Division- Department of Education, Mandaue City, Cebu Philippines \\ ${ }^{2}$ Senior High School, Mandaue City, Cebu, Philippines
}

\begin{abstract}
Parent's occupation is the most important obligation of the parents and should have a privilege to have a suitable work to raise their children. Student's self-esteem is an important aspect of the personality of the person. In this study sought to determine if there has an association between parent's occupation and student's self-esteem. The study was premised on the Stanley Coopersmith Self-esteem Theory proposed by Stanly Coopersmith. This was a descriptive design to determine whether there is a correlation between parents occupation and student's self-esteem. This study has a 245 respondents overall from the different strands (HUMSS, ABM, GAS, STEM and TVL). The tool used on this study for getting the information and data collection is checklist rating scale questionnaire. All the data was analyzed using ANOVA to Carried out the result. The result revealed the $p=0.518$ is greater than the significant level of $0.05(p=0.518<0.05)$. Therefore, the result of this study revealed that parent's occupation is not significantly associated to the selfesteem of the students. Parents that have low or high status of occupation cannot affect the selfesteem of the students. Student's self-esteem is not depending to the work of their parents.
\end{abstract}

Keywords: Academic Performance; Achievements; Confidence; Motivations; Parent's Occupation; Student's Self-Esteem.

Cite This Article: Jerald C. Moneva, Genelyn G. Rozada, and Adrian M. Sollano. (2019). "PARENTS OCCUPATION AND STUDENTS SELF-ESTEEM." International Journal of Research - Granthaalayah, 7(12), 315-324. 10.29121/granthaalayah.v7.i12.2019.326.

\section{Introduction}

Parents Should Have A Privilege to Have A Suitable Work to Raise Their Children, This Is One of The Most Important Obligations of The Parents. It Can Also Predict the Achievements of Their Children. Meanwhile, Students' Self-Esteem Is an Important Aspects of Personality of The Person. Self-Esteem Is the Basis of The Person's Confidence. It Could Be High as Well as Low. A Students That Has High Self-Esteem Tends to Be More Confident and Aware of Their Self-Worth. While, Low Self-Esteem, On the Other Hand Had Have Low Self-Confidence. Self-Esteem Is the Root of Student's Experience To Be Competent And Cope The Basic Challenges In Life. Parents Who Have Low Status of Occupation Can Affect the Self-Esteem To The Students. When Students Lose Their Self-Esteem They May Lose Motivation In Learning. By Building High Self-Esteem to The 
Students Is One of The Most Important in Learning and Parents Can Take to Ensure That Students Will Get Affect to The Criticism from Other People Despite the Occupation of Their Parents. According to Usaini \& Abubakar (2015) Parents Occupation Has A Big Influence on The Students Especially to Their Achievement, Because Of The Confidence That They Can Take Towards the Occupation of Their Parents. (Walter, 2015) High Level of Occupation of The Parents Is the Best Indicators Leading to The Performance of The Achievement of The Students Often Attributed to Their Progress. Noted That $.99 \%$ Of the Students Agree That Occupation of Parents Level Influence Students' Self-Esteem and Academic Performance. Azizollah (2015) The Most Important Factor in Students Performance Is Self-Esteem. Stanley Coopersmith Self-Esteem Theory Self-Esteem Came From The Early Childhood, Because Of The Parents Foundation Of Trust, Conditional Love And Security Given By The Parents To Their Children.

In This, The Research Will Determine the Relationship Between Parents' Occupation and SelfEsteem of Senior High Students in Jagobiao National High School. This Research Is About Knowing How Students Build Their Self-Esteem Towards the Occupation of Their Parents.

The Study Intends to Know the Profile of Occupational Status of Parents and Level of Self-Esteem of Students and Their Association.

\section{Review of Related Literature}

The study parent's occupation and students' self-esteem have been supported by the different articles and it serve as the basis of the study.

Occupation of parents affects students' performance in their academics (Omalde, Kassim, \& Modupe, 2014: Odoh, Ugwuanyi, Odigbo \& Chukwuani, 2017). But, parent's occupation has adverse impact of the academic motivation of learner's success. Students from parents with high occupation level performed poorly compared to those students from parents low and middle occupation level of parents (Walter, 2018). Parents have informal jobs who are mainly selfemployed with job without a guarantee to turnover cannot afford to spend a great deal of time on their children (Usaini\&Abubukar, 2015). Highly educated parents with high or low occupation level had better outcomes compared to their peers whose parents had low educational and occupation level (Gulada, Chillon, Ruiz\& Pavon, 2011). This study confirms parents effect on their children's glycemic control. It is found positive connection between educational and occupational levels of father and mother (Aigha, Majdi, Aljefri, Ali, Alagha, Elhamed\&El-denwi, 2017). Family socio-economic status of parent's state the father's education, occupation and income affects childrens performance (Das \& Sinha, 2017). Parents occupation identify the parent's ability to finance the academic performance also (Gabriel, Muli, Muasya, Moanga \& Mukhunguku, 2016).

A positive impact of the occupation of parents on the financial capacity of the students and their family relationship was observed (Khan, Ayaz, Ghazi\&Khan, 2017). To provide a proof those learners whose parents belong to highest occupation status may have a better degree than their counter parts whose parents belong to the lowest occupation status (Omalde, Kassim \& Modupe, 2014). Occupation of parents and family earnings are the most important variables affecting the growth of kids (Akbar, Shah \& Anwar, 2014). Families with high occupation level are more likely 
to recognize and support their children with their homework and aspire to a good career (Almatalka, 2014). Parents with better work and higher education tend to have a higher education level and performance to their children (Rabo, 2014). Parents occupation status and academic performance has a significant relationship, it is proved that higher income of parents can give better performance on students' performance (Memon, Joubish \& Khurram, 2010). Students show delinquency when their parents are unable to meet their financial needs, because their parents lack of sufficient income and good jobs to give a high quality of education for their students (Ekpo\&Ajake, 2013).

Self-esteem as a human personality has a connection with important human success, failures and frustration (Doodman, Zadeh \&Changizi, 2017). Students will certainly enhance their self-esteem, because they will be proud to be associated to the opportunities for their growth (Ahmad, Zeb, Ullah \& Ali, 2013). It can be concluded that self-esteem has greater beneficial impact on student's accomplishments (Priyadharshini \& Relton, 2014). Two correlating factors supporting one another are self-esteem and academic achievement, there is no doubt that low self-esteem could have contributed to poor academic performance (Neoh, 2018). The connection between self-esteem and academic achievement is one that is considered a well-known fact (Arshad, Zaida \& Mahmod, 2015). Several studies have shown an important connection between self-esteem and academic achievement among learners that self-esteem is a strong predictor of academic achievements for learners (Aluvijeh, Rajati, Limoee \& Jalilian, 2018).

Students with a degree of self-esteem are more effective in finishing assignments and academic achievements and more resistant to life issues and problems (Alavijeh, Rahimi, Matin\&Jalilian, 2018). Self-esteem is correlated with greater stress concentrations to the general populations and has more grade achievements (Alyami, ullah, \& Jaffari, 2012). Various limitations affect the relationship of anxiety, performance and self-esteem among learners, such as their family background, including their parents financial and educational level ( Ntemsia, Triadafyllidou, Papageorgiou \& Roussio, 2017). Family Socio-economic status does not affect students' selfesteem, implying that student's family socio-economic status was not related to self-esteem (Sang, 2015). Parents with distinct social and literacy circumstances seek to cultivate their child and use efficient ways to improve their self-esteem (Azizollah, 2013). The effect of self-esteem and support for the performance of learners has a favorable and less substantial, but self-esteem has a powerful and more important (Shahzad, Ahmed \& Jaffari, 2012). Low self-esteem should be taken to the parents who came from low rate of educated families to insert effort to increase the selfesteem of students (Sahin, Barut\& Ersanli, 2013). Male adolescents ranked significantly higher compared to the self-esteem of female adolescents and there were substantial differences between female and male academic achievement (Joshi \& Srivastava, (2009). Self-esteem is a psychological component, but in other side there has a non-psychological causes that may obstruct the student's academic success. (Ogot, 2015).

\section{Materials and Methods}

\section{Design}

This research study used descriptive correlation to the variables to determine the relationship between parent's occupation and student's self-esteem. 


\section{Environment and Respondents}

This study was conducted in a secondary public school in Mandaue City Division with a respondent of 245 students.

\section{Instrument}

This research study used rating scale questionnaire in gathering data and getting information from the respondents. The rating scale is a type of questionnaire that composed of two variables, first is for parent's occupation and the second is for student's self-esteem. The students need to put a check on the best answer. The first part is a group of works of the parent's; the choices are Blue Collar, Pink Collar, White Collar, Gold Collar, Grey Collar Red Collar, Black Collar and Open Collar. The second part is the self-esteem questions composed of 10 questions, and the choices are, 1-Never, 2-Rarely, 4-Sometimes, 4-Always.

\section{Data Gathering}

Letters were sent to the school principal for approval of the conduct of study and to the advisers in each section in the senior high school for the permission of conducting a research using the set of questionnaires to be distributed to their students. The researcher explains the objective and the purpose of the study. The respondents were given a maximum of 10 minutes to answer the questionnaire. After the respondents answered the questionnaire, the researcher collected the data. It served as the basis in the analysis, interpretation, conclusions, findings and also the recommendation of the study.

\section{Statistical Treatment}

The researcher used the weighted mean and ANOVA to treat the data gathered and to determine the correlation between the two variables especially parent's occupation and student's selfesteem.

\section{Results and Discussion}

Table 1: Profile of Parent's Occupation

\begin{tabular}{|c|c|c|c|c|c|c|c|c|c|}
\hline \multirow[t]{2}{*}{$\begin{array}{c}\text { Job } \\
\text { Category }\end{array}$} & \multirow[t]{2}{*}{$\mathbf{N}$} & \multirow[t]{2}{*}{$\%$} & \multirow[t]{2}{*}{ Mean } & \multirow[t]{2}{*}{$\begin{array}{c}\text { Std. } \\
\text { Deviation }\end{array}$} & \multirow[t]{2}{*}{$\begin{array}{c}\text { Std. } \\
\text { Error }\end{array}$} & \multicolumn{2}{|c|}{$\begin{array}{l}95 \% \text { Confidence } \\
\text { Interval for Mean }\end{array}$} & \multirow[t]{2}{*}{ Minimum } & \multirow[t]{2}{*}{ Maximum } \\
\hline & & & & & & $\begin{array}{l}\text { Lower } \\
\text { Bound }\end{array}$ & $\begin{array}{l}\text { Upper } \\
\text { Bound }\end{array}$ & & \\
\hline $\begin{array}{l}\text { blue } \\
\text { collared }\end{array}$ & 117 & $47.76 \%$ & 38.5385 & 5.07111 & 0.46882 & 37.6099 & 39.467 & 27 & 49 \\
\hline $\begin{array}{l}\text { pink } \\
\text { collared }\end{array}$ & 51 & $20.82 \%$ & 38.8235 & 6.15047 & 0.86124 & 37.0937 & 40.5534 & 27 & 49 \\
\hline $\begin{array}{l}\text { white } \\
\text { collared }\end{array}$ & 37 & $15.10 \%$ & 39.1351 & 6.02385 & 0.99032 & 37.1267 & 41.1436 & 24 & 48 \\
\hline $\begin{array}{l}\text { gold } \\
\text { collared }\end{array}$ & 4 & $1.63 \%$ & 40.000 & 4.32049 & 2.16025 & 33.1251 & 46.8749 & 36 & 46 \\
\hline $\begin{array}{l}\text { black } \\
\text { collared }\end{array}$ & 3 & $1.22 \%$ & 42.6667 & 7.0946 & 4.09607 & 25.0427 & 60.2906 & 35 & 49 \\
\hline $\begin{array}{l}\text { red } \\
\text { collared }\end{array}$ & 17 & $6.94 \%$ & 39.5882 & 4.86131 & 1.17904 & 37.0888 & 42.0877 & 32 & 49 \\
\hline $\begin{array}{l}\text { gray } \\
\text { collared }\end{array}$ & 9 & $3.67 \%$ & 39.2222 & 5.696 & 1.89867 & 34.8439 & 43.6006 & 30 & 45 \\
\hline
\end{tabular}




\begin{tabular}{|l|c|c|c|c|c|c|c|c|c|}
\hline $\begin{array}{l}\text { open } \\
\text { collared }\end{array}$ & 7 & $2.86 \%$ & 34.7143 & 7.43223 & 2.80912 & 27.8406 & 41.588 & 19 & 40 \\
\hline Total & 245 & $100 \%$ & 38.751 & 5.54335 & 0.35415 & 38.0534 & 39.4486 & 19 & 49 \\
\hline
\end{tabular}

The table 1 presented that 8 Collar jobs form the Variable of Parents occupation have three highest frequency. The first highest frequency is Blue Collar Job has 47.76 \%, Next is Pink Collar Job has $20.82 \%$, and third highest frequency IS white collar job has $15.10 \%$. Also, there has three lowest frequency. First is the black collar job has a $1.22 \%$, Second is the gold collar job has a $1.63 \%$ and the third one is the Open Collar Job has a $2.86 \%$. While the overall frequency is $100 \%$. Walter (2018) discovered that parental occupation had a good association to the student performance. Usaini \& Abubakar (2015) found that the base on the regression analysis parents occupation influence academic performance of students. Gualda, Chillon, Ruiz \& Pavon (2011) indicated a fairly consistent positive association between work of parents and cognitive performance.

Table 2: Level of Student Self-Esteem

\begin{tabular}{|l|l|l|}
\hline Indicators & Weighted Mean & Interpretation \\
\hline 1. On the whole I am satisfy with myself & 3.27 & Sometimes \\
\hline 2. At times I think I am no good at all & 2.82 & Sometimes \\
\hline 3. I feel that I have a number of good qualities & 3.00 & Sometimes \\
\hline 4. I am able to do things as well as most other people & 2.98 & Sometimes \\
\hline 5. I do not have much to be proud of & 2.69 & Sometimes \\
\hline 6. I certainly feel useless at times & 2.74 & Sometimes \\
\hline $\begin{array}{l}\text { 7. I feel that I am a person of worth, at least the equal of } \\
\text { others }\end{array}$ & 3.02 & Sometimes \\
\hline 8. I wish I could have more respect for myself & 3.22 & Sometimes \\
\hline 9.All in all, I am inclined to feel I am a failure & 2.61 & Sometimes \\
\hline 10. I take positive attitude towards myself & 3.42 & Always \\
\hline Overall Interpretation & 2.98 & Sometimes \\
\hline
\end{tabular}

Legend: Never (1.00-1.80), Rarely (1.81-2.60), Sometimes (2.61-3.40), Always (3.41-4.00)

The table 2 presents assessment of self-esteem have three highest weighted mean that was interpreted as Always and Sometimes. The highest has a weighted mean of 3.42 with indicator "I take positive attitude towards myself" describes as always while the rest are interpreted as sometimes. The overall weighted mean is 2.98, which is interpreted as "sometimes". This indicates that the data involve here is positively considerable for further statistical analysis about the level of self-esteem of students. Ahmed\& Jaffari (2012) usually self-esteem refers to an overall positive self-assessment of person especially to the students Priyahrshin \& Relton (2014) many students agreed that the impact of higher self-esteem on students have a higher rate on life. Shahzad and Sang (2015) self-esteem can help and improve the academic performance level of the students subsequently. 
Table 3: Profile of parents Occupation and Student's self-esteem Cross tabulation

\begin{tabular}{|l|c|c|c|c|c|}
\hline & Sum of Squares & Df & Mean Square & F & Sig. \\
\hline Between Groups & 191.231 & 7 & 27.319 & .886 & .518 \\
\hline Within Groups & 7306.581 & 237 & 30.829 & & \\
\hline Total & 7497.812 & 244 & & & \\
\hline
\end{tabular}

In these result, the null hypothesis is rejected because the p-value (.518) is greater than the alpha significance level of $0.05(\mathrm{p}=0.518)<(\alpha=0.05)$. So, it is concluded that student's self-esteem and parent's occupation are not significant to each other. Sang (2015) mentioned that socio-economic status including parents occupation and education are not significantly associated to each other. Further, Azizollah (2013) the result of the study indicate that the parents occupation is not a reliable predictor of the student's self-esteem. Outbir (2018) found a weak and negative correlation between socio-economic status, parental education and occupation towards the self-esteem of the students.

\section{Conclusions and Recommendations}

Parents who have a high status of occupation are expected that their students have high self-esteem and parents that have a low status of occupation tend that their students having a low self-esteem towards their academic performance. But based on the study, it is shown apparently that having high self-esteem of students are not connected of what occupation their parents have, students having a high self-esteem gives them an advantage in their daily lives; they can use it to pursue their dreams also. It was observed also that self-esteem of students is not depending on the occupation of their parents if their parents have a high status of occupation, it doesn't mean that self-esteem of students is also high, and vice-versa. The self-esteem of the students is based on their abilities, confidence and respect to their selves, but self-esteem has an important factor to the academic achievements of students, especially to the senior high school students.

Parents can assist their children on how they can maintain their self-esteem using their abilities in life and their different strengths can help to have a high self-esteem. Parents have nothing to worry about their work for whatever it is; it does not affect the self-esteem of their children.

\section{Acknowledgements}

First of all, I am very thankful to our Almighty God for giving me wisdom, strength and knowledge to surpass the trails I encounter doing this research paper.

To our principal Ms. Juvy M. Sosas for providing me and also to my co-students a necessary facility.

To my beloved adviser Ms. Faith Ranario for always there to motivate me through my ups and down making this research through the semester.

I would like to express my deepest gratitude to my parents to their encouragement, financial assistance as well as their full support to finish this research. 
And I take this opportunity to express my sincere thanks for all the people especially to my classmates for their unceasing encouragement, help, knowledge and equipment to finish this research wonderful.

\section{Appendices}

\section{Appendix A}

Direction: Read each statement below carefully. Written below are the statements that are related to the variables of the study. After reading each statement s put a check mark for the parent's occupation and rate your answers for the student's self-esteem using 1-Never, 2-Rarely, 3Sometimes, 4-Always.

\section{Parents Occupation}

1) BLUE COLLAR (custodial working, maintenance mechanic, aircraft mechanic, food service working, misc transportation mobile, equipment maintenance, electrician, painter, cook, pipefitting, machining, electronic integrated, system mechanic, welding engineering, and equipment operating, construction worker, Baker, driver and vendor).

2) PINK COLLAR (Babysitter, florist, day care worker, nurse, housewife, librarians, maids, flight attendant, secretaries).

3) WHITE COLLAR (Police detective, senior corporate executive, surgeon, attorney, physician, scientist jobs, engineering jobs, administrative jobs, teacher, politician, company clerk, dentist, architect, security guard, call center, ofw, self-employed).

4) __ GOLD COLLAR (Doctor, lawyer, low wage worker).

5) BLACK COLLAR (Miners, oil workers, artist, graphic designers, video producers).

6) _ RED COLLAR (Government Jobs).

7) _ GREY COLLAR (IT, health care professions, childcare professions, skilled technicians, technology workers, technicians).

8) OPEN COLLAR (Online selling Or Online Jobs).

\section{Appendix B}

Appendix B: Student's Self-Esteem

\begin{tabular}{|c|c|c|c|c|}
\hline \multirow{3}{*}{$\begin{array}{l}\text { Statements } \\
\text { On the whole I am satisfy with myself }\end{array}$} & 4 & 3 & 2 & 1 \\
\hline & & & & \\
\hline & & & & \\
\hline I feel that I have a number of good qualities & & & & \\
\hline I am able to do things as well as most other people & & & & \\
\hline I feel I do not have much to be proud of & & & & \\
\hline I certainly feel useless at times & & & & \\
\hline I feel that I am a person of worth, at least the equal of others & & & & \\
\hline I wish I could have more respect for myself & & & & \\
\hline All in all, I am inclined to feel I am a failure & & & & \\
\hline I take positive attitude toward myself & & & & \\
\hline
\end{tabular}




\section{References}

[1] Ahmad, I., Zeb, A., Ullah, S., \& Ali, Z. (2013). Relationship between self-esteem and academic achievements of students: a case of government secondary schools in district swabi, kpk, Pakistan. International Journal Soc. Sci \& Education, 3(2), 361-369.

URL:https://pdfs.semanticscholar.org/7fe0/6dafc0b690fa267d3959f96940cd480f495.pdf

[2] Aigha, M., Majdi, W., Aljefri, H., Abdelfattah, M., Alagha, A., Elhameed, I.A. \& El-derwi, D.A. (2017). Effects of parent's educational level and occupational status on child glycemic control. Journal of Patient Care, 3(2), 1-3. DOI: 10.4172 12573-4598.10000130.

[3] Alavijeh, M.M., Rahimi, H., Matin, B.K. \& Jalilian, F. (2018). Self-esteem and academic achievement among students of kermash university of medical sciences. Education Res Med Sci, 7(1), 1-3. DOI: 10.5812/erms.79919.

[4] Alavijeh, M.M., Rahimi, H., Limoee, M. \& Jalilian, F. (2018). Self-esteem and academic achievement among students of kermash university of medical sciences. Education Res Med Sci, 7(1), 1-3. DOI: 10.5812/erms.79919.

[5] Al-matalka, F.I.M. (2014). The influence of parental socio-economic status on their involvement at home. International Journal of Humanities and Social Science, 4(5), 146-154. URL: http://www.ijhssnet.com/journals/Vol_4_No_5_March_2014/15.pdf

[6] Alyami, M.H., Ullah, E. \& Sundram, F. (2017). The impact of self-esteem academicself-efficacy and perceived stress on academic performance. A cross-sectional study on Saudi psychology students. European Journal of Educational Sciences, 4(3), 51-68. URL: https://researchspace.auckland.ac.nz/handle/2292/42863

[7] Arshad, m., Zaida, S.M.I.H. \& Mahmood, K. (2015). Self-esteem \& academic performance among university students. Journal of education and Practice, 6(1). URL: https://files.eric.ed.gov/fulltext/EJ1083788.pdf

[8] Azizollah, A. (2013). The relationship between childrens and parents educational level shirani, nahid. International Journal of Academic Research in Progressive Education and Development, 2(3), 11-21. URL: file:///C:/Users/carlos\%20pc\%207/Downloads/2013-4.pdf

[9] Das, C. G. \& Sinha, S. (2017). Effect of socio-economic status on performance in mathematics among students of secondary schools of Guwahati city. Journal of Mathematics (JOSR-JM), 13(1), 22-33.

URL:file:///C:/Users/carlos\%20pc\%207/Downloads/Astudyontheeffectofsocioeconomicstatusoni nterestinmathematicsamongstudentsofdifferentcategoriesofschoolsofGuwahati.pdf

[10] Doodman, P., Zadeh, M.A. \& Changizi, B. (2017). Study the relationship between self-esteem and academic achievements among high school students in lamerd city. International Journal of Scientific Study, 5(3), 221-226. DOI: 10.7354.

[11] Ekpo, T.E. \& Ajake, U. E. (2013). Family socio-economic status and delinquency among senior secondary school's students in calabar state, cross river state, Nigeria. American International Journal of Contemporary Research, 3(4), 83-88. URL: http://www.aijcrnet.com/journals/Vol_3_No_4_April_2013/9.pdf

[12] Gabriel, M. N., Muli, N.L., Muasya, I., Moanga, L. \& Mukhungulu, M. (2016). Parents socioeconomic status and student's achievement in selected secondary schools in urban informal settlements in westlands divisions, Nairobi country. International Journal of Education and Social Science, 3(1), 43-53. URL:

https://www.researchgate.net/publication/333105438_Parental_socio_economic_status_academic _achievement_in_selected_secondary_schools_in_urban_informal_settlements_in_Westlands_Di vision_Nairobi_county

[13] Gualda, R.C., Chillon, P., Ruiz, Jonathan, R. \& Pavon, D.J. (2011). Associations between parental educational/occupational levels and cognitive performance in spanish adolescents. The Avena Study. 23(3). URL: 
file:///C:/Users/carlos\%20pc\%207/Downloads/Associations_between_parental_educationaloccup atio.pdf

[14] Joshi, S. \& Srivastava, R. (2009). Self-esteem and academic achievement of adolescents. Journal of the Indian academy of Applied Psychology, 35(33), 33-38. URL: http://medind.nic.in/jak/t09/s1/jakt09s1p33.pdf

[15] Kahn, S.N.I.V., Ayaz, M. \& Ghazi, S.R. (2017). Impact of parent's occupation on student's selfconcept at secondary level. International Journal of Academic Research in business and Social Sciences, 7(1), 46-53. URL:

http://hrmars.com/hrmars_papers/Impact_of_Parents\%E2\%80\%99_Occupation_on_Students_Sel f-Concept_at_Secondary_Level.pdf

[16] Memon, G.R., Joubish, M.F. \& Khurram, M.S. (2010). Impact of parental socio-economic status on student's educational achievement at secondary schools on students malir, Karachi. Middle-East Journal of Scientific Research, 6(6), 678-687. URL: https://pdfs.semanticscholar.org/f00d/a1f50600e59858cf90f6d80758149f7d66d8.pdf

[17] Neoh, C.F., Muda, M.R. \& Ahmat, S.N. (2018). Self-esteem level and its relationship to academic performance among undergraduate pharmacy students in a malaysian public university. Indian Journal of Pharmaceutical Education and Research, 52(2), 197-201. DOI: 10.5530/ijper.52.2.21.

[18] Ntemsia, S., Triadafyllidou, S., Papageorgiou, E. \& Roussou, K. (2017). Self-esteem and anxiety levels of students at the technological educational institute of Athens-planning of interventions. Health Science Journal, 11(3), DOI: 10.21767/191-809x.1000512.

[19] Odoh, L.C., Ugwuanyi, U.B., Odigbo, B. \& Chukwuani, N.V. (2017). Influence of parental occupation and level of education on academic performance of accounting students in nigeria. Research on Humanities and Social Science, 7(10). URL: file:///C:/Users/carlos\%20pc\%207/Downloads/JournalarticleonParentaleffectonperformance.pdf

[20] Omalde, A., Kassim, A. \& Modupe, S. (2014). Relative effects of parent's occupation, qualification and academic motivation of wards on student's achievements in senior secondary mathematics in ogon state. Journal of Education and Practice, 5(22). URL: https://pdfs.semanticscholar.org/865b/11bdc80073138d07276b94268f32b3c99989.pdf

[21] Priyadharshini, J. \& Relton, A. (2014). Self-esteem and academic performance of freshmen at karunya university. Journal of Humanities and Social SCIENCE, 19(4), 21-26. URL:https://pdfs.semanticscholar.org/9381/e61f162017e3af715da6b58f459321cbd051.pdf

[22] Rabo, M.V. (2018). An appraisal of parental background and students' performance in nigeria. Journal of Research \& Method in Education, 8(6), 1-5. URL: http://www.iosrjournals.org/iosrjrme/papers/Vol-8\%20Issue-6/Version-5/A0806050105.pdf

[23] Sahin, E. Barut, Y. \& Ersanti, E. (2013). Parental education level positivity affects self-esteem of Turkish adolescents. Journal of Education and Practice, 4(20), 87-95. URL: https://files.eric.ed.gov/fulltext/ED555409.pdf

[24] Sang, C.C. (2015). Relationship Between student's family socio-economic status, self-esteem. International Journal of Education and Research, 3(2), 647-656. URL: https://www.ijern.com/journal/2015/February-2015/52.pdf

[25] Shah, M.A.A. \& Anwar, M. (2014). Impact of parent's occupation and family income on children performance. International Journal of Research, 1(9), 606-612. URL: https://pdfs.semanticscholar.org/4b89/522d6096e58ca4bbbc7d8c36df5ec9ccf66e.pdf

[26] Shahzad, A., Ahmed, T. \& Jaffari, S. (2014). Impact of self-esteem and support on students' performance. Management and Marketing, 5(2), 353-358. URL:

file:///C:/Users/carlos\%20pc\%207/Downloads/TheEffectofSelfEsteemonStudentAchievement.pdf

[27] Usaini, M.I. \& Abubukar, N.B. (2015). The impact of parent's occupation on academic performance of secondary school students in kuala Terengganu. Multilingual Academic Journal of Education and Social Sciences, 3(1), 112-120. URL: 
http://hrmars.com/hrmars_papers/The_Impact_of_Parents\%E2\%80\%99_Occupation_on_Academ ic_Performance_of_Secondary_School_Students_in_Kuala_Terengganu.pdf

[28] Walter, K. (2018). Influence of parental occupation and parental level of education on students' academic performance in public day secondary schools. International Journal of Research and Innovation in Social Scienece, 2(2), 201-211. URL:

https://www.rsisinternational.org/journals/ijriss/Digital-Library/volume-2-issue-12/201-211.pdf

*Corresponding author.

E-mail address: monevajerald5@ gmail.com 